\title{
On the disulphide bonds of rhodopsins
}

\author{
Saad AL-SALEH, Michael GORE and Muhammad AKHTAR* \\ Department of Biochemistry, University of Southampton, Bassett Crescent East, Southampton SO9 3TU, U.K.
}

\begin{abstract}
Carboxymethylation using ${ }^{14} \mathrm{C}$ - or ${ }^{3} \mathrm{H}$-labelled iodoacetic acid has been used to identify the cysteine residues in bovine rhodopsin involved in the formation of the two intramolecular disulphide bridges. Iodo[2-14 C]acetic acid was used to modify 5.8-5.9 residues of cysteine under non-reducing conditions. After dialysis and reduction of disulphide bridges by 2 -mercaptoethanol, iodo[ $\left[2-{ }^{3} \mathrm{H}\right]$ acetic acid was employed to covalently modify 3.3-3.6 residues of cysteine. Peptide purification and sequencing has unambiguously shown that cysteine residues 322 and 323 are only carboxymethylated after reduction of disulphide bridges. Indirect evidence presented, now coupled with the earlier finding [Findlay \& Pappin (1986) Biochem. J. 238, 625-642] suggests that the other disulphide bridge is formed between cysteine residues 110 and 187. A comparison is made of all the sequences of mammalian rhodopsins and colour pigments and attention is drawn to the fact that whereas Cys-322 and Cys-323 are conserved only in three rhodopsins (bovine, ovine and human), the residues corresponding to Cys-110 and Cys-187 are found in all the visual proteins (from rods as well as human cones).
\end{abstract}

\section{INTRODUCTION}

Rhodopsin, the photoreceptor substance found in the rod outer segments of the retina, is composed of a glycoprotein opsin linked to 11-cis-retinal [1]. Our previous studies have established the Schiff-base nature of this linkage ([2,3]; also see [4]) and have identified $[5,6]$ the retinal-binding lysine residue in the primary sequence of bovine rhodopsin $[7,8]$. The comparison of the amino acid sequence data (determined or predicted from DNA sequence information) points to features common to all visual pigments [9-12]. The $C$-termini of the pigments are characterized by a stretch of hydrophilic amino acids and contain several phosphorylation sites. The retinal-binding lysine residue is located towards the $C$-terminal quarter of the molecule and has been shown to occupy position 296 in bovine [5,9] and ovine rhodopsin [13], and similar locations have been inferred for pig [13], horse and four human pigments [14-16].

All the three rod pigments (bovine, ovine and human) studied to date have similar amino acid sequences and, in particular, contain ten highly conserved cysteine residues. The work of De Grip et al. [17] performed in the early 1970 s showed that, under denaturing conditions, $1 \mathrm{~mol}$ of bovine rhodopsin reacted with about $6 \mathrm{~mol}$ of 5,5'-dithiobis-(2-nitrobenzoic acid), thus suggesting the presence of six reduced cysteine residues and highlighting the probability that the remaining four residues were involved in the formation of two disulphide bridges. Fragmentary evidence obtained during various structural studies has pointed to the fact that the cysteine residues at positions 140 in ovine [18], 167 in ovine [19], 222 in ovine [19], 264 in ovine [20] and 316 in ovine and bovine $[18,20,21]$ are present in the thiol forms, and that at position 110 in ovine [22] may be involved in the formation of one of the disulphide bonds. The present work addresses itself to the identification of the positions of the two forms of cysteine (-SH and -S-S-) in bovine rhodopsin using a double-labelling approach.

\section{EXPERIMENTAL}

\section{Materials}

Cattle eyes were collected from a local slaughterhouse (FMC Meat, Salisbury, Wilts., U.K.). The retinae were immediately removed and stored in a light-proof flask. They were either processed on the same day at the laboratory or stored in the dark at $4{ }^{\circ} \mathrm{C}$ for processing the following day.

Iodo $\left[2-{ }^{3} \mathrm{H}\right]$ acetic acid, iodo $\left[2-{ }^{14} \mathrm{C}\right]$ acetic acid were obtained from The Radiochemical Centre, Amersham, Bucks., U.K. Control-pore glass was obtained from Sigma and derivatized as described in [23].

\section{Measurement of radioactivity}

The radioactivity was determined by adding $0.1-1.0 \mathrm{ml}$ of aqueous samples to $10 \mathrm{ml}$ of Tritoscint [xylene $(2$ litres), Synperionic nxp (1 litre), 2,5-diphenyloxazole (PPO, $12 \mathrm{~g}$ ) and 1,4-bis-(4-methyl-5-phenyloxazol-2yl)benzene (dimethyl-POPOP; $1.5 \mathrm{~g}$ )]. The chemicals for the scintillation fluid were obtained from the following suppliers: synperionic nxp from Cargo Fleet Chemical Co., Stockton-on-Tees, Cleveland, U.K.; PPO and dimethyl-POPOP from G \& G Chemicals, Ascot, Berks., U.K.

\section{Preparation of rod outer segments}

Rod outer segments were prepared from freshly collected retinae and stored in water at $-20^{\circ} \mathrm{C}$ essentially as described by Sale et al. [24]. In this procedure at no stage of the preparation or storage is a thiol reagent used. However, in view of the unexpected finding of a disulphide bond between adjacent cysteine residues, further experiments were undertaken in which the free thiol groups in the protein were protected from possible oxidation by the inclusion of $1 \mathrm{~mm}$-dithiothreitol at all stages including storage. The yield of rhodopsin in our experiments was $20 \mathrm{nmol} /$ retina with an $A_{280} / A_{500}$ of $1.7-2.1$.

Abbreviations used: PTH, phenylthiohydantoin; h.v.p.e., high-voltage paper electrophoresis.

* To whom correspondence and reprint requests should be addressed. 
Non-reductive $S$-carboxymethylation

The pellet of rod outer segments (120 mg of protein) was taken up in water $(20 \mathrm{ml})$ and mixed with SDS $(390 \mathrm{mg})$ and $\mathrm{NaHCO}_{3}(390 \mathrm{mg})$. After the contents had dissolved (up to $1 \mathrm{~min}$ ), iodo[2-14 C]acetic acid (120 mg; $0.96 \times 10^{6}$ d.p.m. $\left./ \mu \mathrm{mol}\right)$ was added and the solution stored at room temperature in the dark for $2 \mathrm{~h}$. As far as practicable, all preceding operations were carried out under an atmosphere of argon. The protein was then precipitated from the detergent solution essentially as described in [5]. The reaction mixture was cooled to $0^{\circ} \mathrm{C}$ and $4 \mathrm{vol}$. of ice-cold aq. $80 \%(\mathrm{v} / \mathrm{v})$ methanol were added dropwise. The suspension was left at $0{ }^{\circ} \mathrm{C}$ for $30 \mathrm{~min}$ and then centrifuged for $15 \mathrm{~min}$ at $40000 \mathrm{~g}$. The pellet was washed once with the same mixture and several times with water. A portion of the pellet was removed for analysis and was found to contain $5.6 \times 10^{6} \mathrm{~d}$.p.m. $/ \mu \mathrm{mol}$ of protein, corresponding to the modification of $5.8-\mathrm{SH}$ groups. Another experiment performed in parallel gave $5.67 \times 10^{6}$ d.p.m. $/ \mu$ mol, showing the modification of 5.9 $-\mathrm{SH}$ groups.

\section{Reductive $\boldsymbol{S}$-carboxymethylation}

The preceding $S$-carboxymethylated protein $(100 \mathrm{mg}$; about $2.5 \mu \mathrm{mol}$ ) was suspended in $1.44 \mathrm{M}$-Tris/ $\mathrm{HCl}$ buffer, pH $8.6(4.8 \mathrm{ml})$ and mixed with solid SDS $(120 \mathrm{mg})$ and a $5 \%(\mathrm{w} / \mathrm{v})$ solution of EDTA $(0.48 \mathrm{ml})$. The mixture was then made up to $10 \mathrm{ml}$ with water, treated with 2-mercaptoethanol $(2.0 \mathrm{ml})$ and left at room temperature under an atmosphere of argon for $2 \mathrm{~h}$. The resulting solution was then transferred to a dialysis tube, which was connected to a balloon of argon, and dialysed against three changes of $\mathrm{O}_{2}$-free distilled water, until the concentration of 2-mercaptoethanol was decreased to about $5 \mathrm{~mm}$. After adjusting the $\mathrm{pH}$ to 8.6 with $1.44 \mathrm{M}$-Tris/ $\mathrm{HCl}$ buffer, the protein solution was treated with iodo[2- $\left.{ }^{3} \mathrm{H}\right]$ acetic acid $(300 \mathrm{mg}$; $5.3 \times 10^{6}$ d.p.m. $\left./ \mu \mathrm{mol}\right)$ in $1 \mathrm{M}-\mathrm{NaOH}(0.9 \mathrm{ml})$ and the mixture left for $2.5 \mathrm{~h}$ in the dark at room temperature under an atmosphere of argon and then dialysed overnight against 5 litres of distilled water. The protein was isolated by precipitation with ice-cold aq. $80 \%$ methanol as described above. An analysis of a portion of the pellet showed the incorporation of $1.7 \times 10^{7}$ and $1.9 \times 10^{7} \mathrm{~d}$.p.m. of ${ }^{3} \mathrm{H} / \mu \mathrm{mol}$ of protein, corresponding to the modification of 3.3-3.6 -SH groups in two parallel experiments.

\section{Digestion of the $\left[{ }^{14} \mathrm{C},{ }^{3} \mathrm{H}\right]$ carboxymethyl protein with CNBr and extraction of water-soluble peptides}

The $\left[{ }^{14} \mathrm{C},{ }^{3} \mathrm{H}\right]$ carboxymethyl-protein ( $2 \mu \mathrm{mol}$ ), prepared as described above, was dissolved in $3.5 \mathrm{ml}$ of $90 \%$ (v/v) formic acid and diluted with water to give a final formic acid concentration of $70 \%(\mathrm{v} / \mathrm{v})$. The solution was treated with $\mathrm{CNBr}$ (56 mg, about 280 -fold molar excess over protein) [25] and the mixture left at room temperature for $24 \mathrm{~h}$. Thereafter the reaction mixture was diluted approx. 10-fold with water and freeze-dried to complete dryness. The residue was then extracted several times with water and the combined aqueous extract freeze-dried.

Analysis of water-soluble peptides by high-voltage paper electrophoresis (h.v.p.e.)

A sample of the above mixture $\left(3.7 \times 10^{4}\right.$ d.p.m. of ${ }^{3} \mathrm{H}$ and $1.2 \times 10^{4}$ d.p.m. of ${ }^{14} \mathrm{C}$ ) was loaded on to a Whatman
(3MM) chromatography paper and after being sprayed with pyridine/acetic acid/water (25:1:225, by vol.), $\mathrm{pH}$ 6.4, was subjected to h.v.p.e. in the same solvent for $105 \mathrm{~min}$ at $2 \mathrm{kV}$. The paper was dried, sprayed with ninydrin, and the eight ninhydrin-positive bands were then soaked in $1 \mathrm{ml}$ of water for $2 \mathrm{~h}$ and their radioactivities.determined. Of the clearly separated ninhydrin-positive bands, one (peptide A) at $19 \mathrm{~cm}$ from the origin toward the cathode, contained ${ }^{14} \mathrm{C}$ only and another (peptide $\mathrm{C}$ ), at $5 \mathrm{~cm}$ toward the anode, was labelled predominantly with ${ }^{3} \mathrm{H}$. For further analysis these were isolated by preparative h.v.p.e.

A second sample of water-soluble peptides was analysed as described above, but at $\mathrm{pH} 3.5$ for $2.5 \mathrm{~h}$ using pyridine/acetic acid/water (1:10:289 by vol.) to give nine ninhydrin-positive bands. One of the labelled peptides that was poorly resolved during electrophoresis at $\mathrm{pH} 6.4$ was now present as a discrete band (peptide B) at $11 \mathrm{~cm}$ from the origin towards the cathode and contained predominantly ${ }^{14} \mathrm{C}$ (but also some ${ }^{3} \mathrm{H}$ ) and was isolated by preparative electrophoresis.

\section{Preparative h.v.p.e. of the water-soluble peptides}

A sample of water-soluble peptides $\left(1.2 \times 10^{6} \mathrm{~d}\right.$.p.m. of ${ }^{3} \mathrm{H}$ and $0.36 \times 10^{6}$ d.p.m. of ${ }^{14} \mathrm{C}$ ) was applied to the paper as a $22 \mathrm{~cm}$ band and the mixture separated by h.v.p.e. at pH 6.4 as described above. A guide strip was cut from each side of the electrophoretograms and sprayed with ninhydrin. The areas corresponding to the ninhydrinpositive spots were carefully marked, cut and then eluted for 6-8 $\mathrm{h}$ with water. A portion of each peptide eluant was used for the determination of radioactivity and the remaining samples freeze-dried. The residues corresponding to the peptides $A$ and $C$ were used for the determination of the sequence of amino acids.

Another similar sample of the water-soluble peptides was separated at $\mathrm{pH} 3.5$ to obtain peptide B.

\section{Attachment of the labelled peptides to glass}

Peptide C. A $50 \mathrm{mg}$ portion of phenylene diisothiocyanate-activated aminopropylaminoethyl-glass [pore diameter $24 \mathrm{~nm}(240 \AA)$, mesh size 120-200] [26,27] was added in three portions to a stirring solution of the peptide C (about 20 nmol, 180000 d.p.m. of ${ }^{3} \mathrm{H}$ ) in $0.3 \mathrm{ml}$

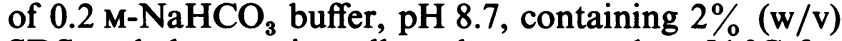
SDS and the reaction allowed to proceed at $54^{\circ} \mathrm{C}$ for $60 \mathrm{~min}$. In two independent experiments, between 30 and $60 \%$ of the radioactivity originally used was removed from the solution. After filtration the glass was washed several times with $1 \%(w / v)$ SDS solution and then methanol. A portion of the glass on radiochemical analysis showed that only $30 \%$ of the expected ${ }^{3} \mathrm{H}$ was immobilized on glass. This low recovery of radioactivity is not surprising, since the quench-correction program used in the present study is suitable only for the accurate measurement of radioactivity of compounds soluble in the scintillation fluid. A $40 \mathrm{mg}$ portion of glass with an apparent radioactivity of 25000 d.p.m. was used for the Edman degradation in Fig. 1(c) below.

Peptide A. A dried sample of Peptide A (about $15 \mathrm{nmol}, 15000$ d.p.m. of ${ }^{14} \mathrm{C}$ ) was dissolved in trifluoroacetic acid $(0.5 \mathrm{ml})$ and after $30 \mathrm{~min}$ the acid was removed by blowing a stream of argon over the solution and the container then left in a vacuum desiccator for $1 \mathrm{~h}$. The residue was dissolved in freshly dried dimethyl- 

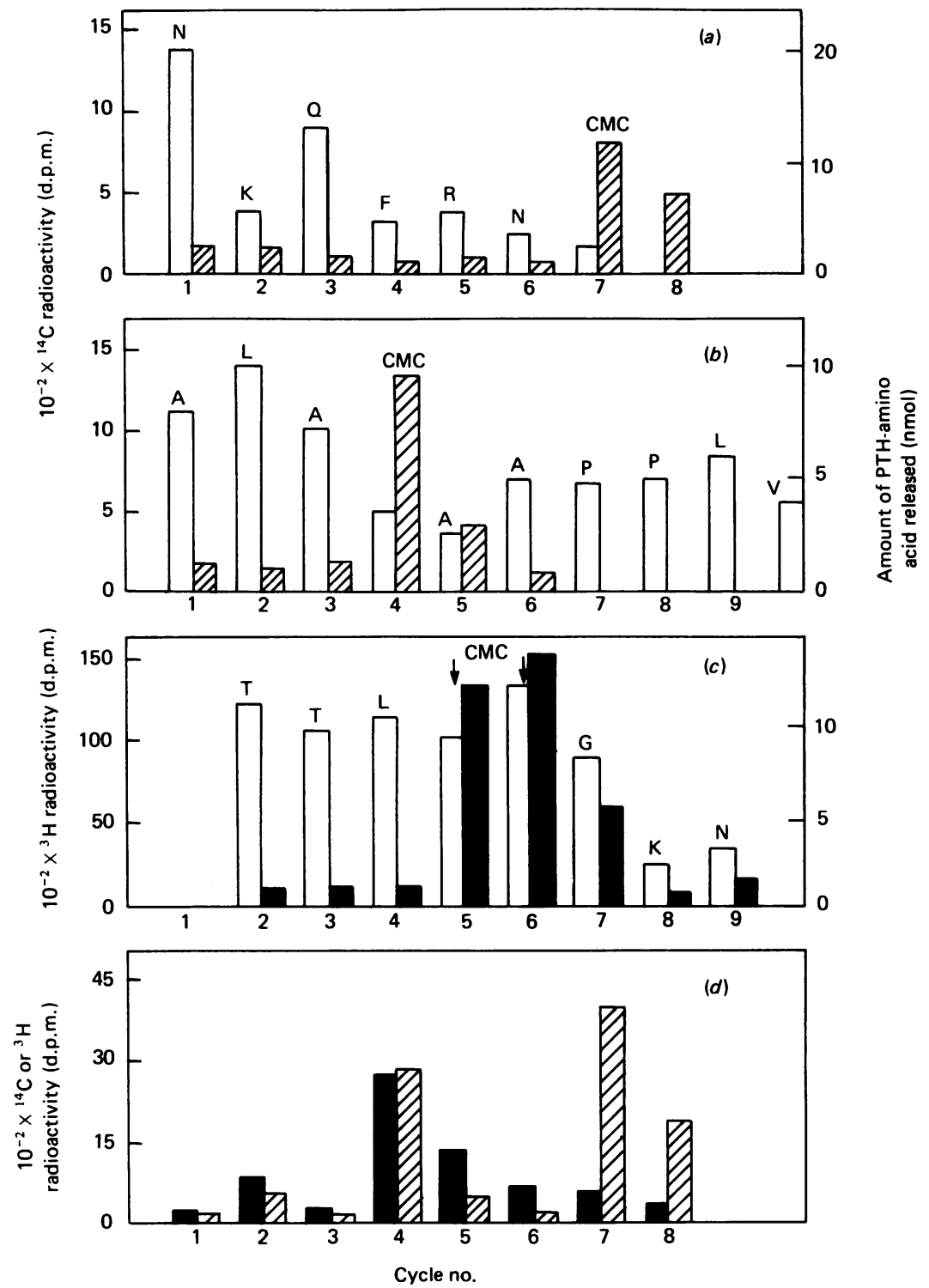

Fig. 1. Analysis of the PTH-amino acids and/or of the isotope $\left({ }^{14} \mathrm{C}\right.$ and $\left.{ }^{3} \mathrm{H}\right)$ released at each cycle of the Edman degradation from peptides $\mathrm{A}(\boldsymbol{a}), \mathrm{B}(\mathrm{b})$ and $\mathrm{C}(\boldsymbol{c})$ or the mixture of water-soluble peptides

The peptides were purified and immobilized as described in the Experimental section. The vertical axes described the amount of radioactivity $(\square, \square)$ and the amount (nmol, $\square$ ) of each PTH-amino acid (indicated by the single-letter notation; CMC is carboxymethylcysteine) released. In these experiments the radioactivity due to both ${ }^{14} \mathrm{C}\left(\mathrm{B}_{\mathrm{a}}\right)$ and ${ }^{3} \mathrm{H}(\square)$ was measured. Since in $(a)$ and $(b)$ no ${ }^{3} \mathrm{H}$ and in $(c)$ no ${ }^{14} \mathrm{C}$ was detected, these data are not included. $(d)$ Describes only the release of radioactivity $\left({ }^{14} \mathrm{C}\right.$ and $\left.{ }^{3} \mathrm{H}\right)$ when a total mixture of water-extracted peptides from $\mathrm{CNBr}$-treated rhodopsin was subjected to the Edman degradation. The repetitive yields of the Edman degradation for peptides A, B, and C were 92,93 and $93.5 \%$ respectively.

formamide $(0.2 \mathrm{ml})$ and stirred at $54^{\circ} \mathrm{C}$ with dry aminopropyl-glass $[7.5 \mathrm{~nm}(75 \AA)$ pore size; mesh size $200 ; 50 \mathrm{mg}$ ] [28] for $1 \mathrm{~h}$, when practically all the radioactivity originally present in solution was removed. However, the radioactivity retained on the glass was only $40 \%$ of that expected from the loss and was detected in the ${ }^{14} \mathrm{C}$ as well as the ${ }^{3} \mathrm{H}$ channel, thus highlighting the fact that scintillation counting only provides qualitative information on the radioactivity associated with particulate samples. A $40 \mathrm{mg}$ sample of the glass containing an apparent radioactivity of 5000 d.p.m. was used in the analysis shown in Fig. 1(a).
Peptide B. Peptide B (about 15 nmol, 19000 d.p.m. of ${ }^{3} \mathrm{H}$ and 13000 d.p.m. of ${ }^{14} \mathrm{C}$ ) was immobilized by the homoserine lactone coupling procedure used for peptide $\mathrm{A}$. Interestingly, in this case only the ${ }^{14} \mathrm{C}$ was removed from the solution while the ${ }^{3} \mathrm{H}$ remained in the solution. The analysis of the glass showed the immobilization of about 9000 d.p.m., but, for the reason indicated above, the nature of the isotope responsible for the emission could not be discerned at this stage. Edman degradation of $40 \mathrm{mg}$ of glass containing 8000 apparent d.p.m. clearly showed that only ${ }^{14} \mathrm{C}$ was released with PTH-carboxymethylcysteine (Fig. 1b). 
Mixture of water-soluble peptides. The entire mixture of water-soluble peptides $\left(4 \times 10^{5}\right.$ d.p.m. of ${ }^{3} \mathrm{H}$ and $1.4 \times 10^{5}$ d.p.m. of ${ }^{14} \mathrm{C}$ ) was subjected to homoserine lactone coupling on aminopropyl-glass $(100 \mathrm{mg})$ when, after $1 \mathrm{~h}$, about $25 \%$ of the radioactivity had been removed from the solution. The derivatized glass was used for Edman degradation in three separate experiments. The first pilot run suggested that in this case a substantial amount of radioactivity was trapped in, but not covalently bound to, the glass; therefore, in a more critical run, the glass was washed in the sequencer with trifluoroacetic acid for $7 \mathrm{~min}$ before the normal cycle of Edman degradation was initiated. The experiment of Fig. 1 $(d)$ was performed by using this protocol with $30 \mathrm{mg}$ of the derivitized glass.

\section{RESULTS}

In a series of five experiments under non-reducing conditions $5.6-6 \mathrm{~mol}$ of carboxymethyl groups were found to be incorporated $/ \mathrm{mol}$ of rhodopsin. The stoichiometry of this incorporation agrees with the previous estimates [17] of the number of free -SH groups in rhodopsin and was unaltered when $1 \mathrm{~mm}$-dithiothreitol was present throughout the preparation of rod outer segments.

In preliminary experiments it was found that the disulphide bonds of rhodopsin were relatively resistant to reductive cleavage, and this conversion was, therefore, achieved through the treatment of the above-prepared $\left[{ }^{14} \mathrm{C}\right]$ carboxymethylated protein in SDS with $2 \mathrm{M}-2$ mercaptoethanol for $2 \mathrm{~h}$. Thereafter the concentration of 2-mercaptoethanol was decreased to $<5 \mathrm{~mm}$ by dialysis under strictly anaerobic conditions using a blanket of argon. The reaction mixture was then subjected to the second stage of carboxymethylation with iodo $\left[2-{ }^{3} \mathrm{H}\right]-$ acid/water (70:27:3, by vol.) and further fractionated, the present study is entirely concerned with the water-soluble peptides, which were purified by paper electrophoresis at $\mathrm{pH} 6.4$ or 3.5 and three labelled peptides designated peptides A, B and C were obtained. Peptides A and B were attached to aminopropyl-glass [7.5 $\mathrm{nm}(75 \AA)$ pore size] by the homoserine coupling method [28], whereas peptide $C$ was immobilized on glass $[26,27]$ activated with 4-phenylene di-isothiocyanate [23] and these were then analysed by solid-phase sequencing [29].

The sequence of peptide A corresponded to that of rhodopsin from residue 310 to 317 and the radioactivity released with PTH-carboxymethylcysteine at the seventh cycle (Cys-316) of Edman degradation [30] was entirely ${ }^{14} \mathrm{C}$ (Fig. 1). The sequence of the first eight amino acids of Peptide B showed it to be the cyanogen bromide fragment corresponding to residues 164 to 183 of bovine rhodopsin and in this case once again the radioactivity released with PTH-carboxymethylcysteine at the 4th cycle (Cys-167) was that from the ${ }^{14} \mathrm{C}$ label used for the alkylation of the free -SH groups of rhodopsin. These findings are in agreement with the previous assignments that in rhodopsin Cys-316 [18,21] and Cys-167 [19] are present in the -SH form. It should be borne in mind that the specific radioactivity of iodo $\left[{ }^{14} \mathrm{C}\right]$ acetic acid used in the carboxymethylation of the free -SH groups of rhodopsin was only $1 / 5$ that of iodo $\left[{ }^{3} \mathrm{H}\right]$ acetic acid used in the reductive-carboxymethylation. Despite this bias in favour of ${ }^{3} \mathrm{H}$ that this isotope was not found associated with Cys-167 and Cys-316 is an important observation (see below) and shows that under our experimental conditions, the two stages of carboxymethylation had occurred with a remarkable degree of fidelity.

The sequences of the four peptides were as follows (Hse is homoserine):

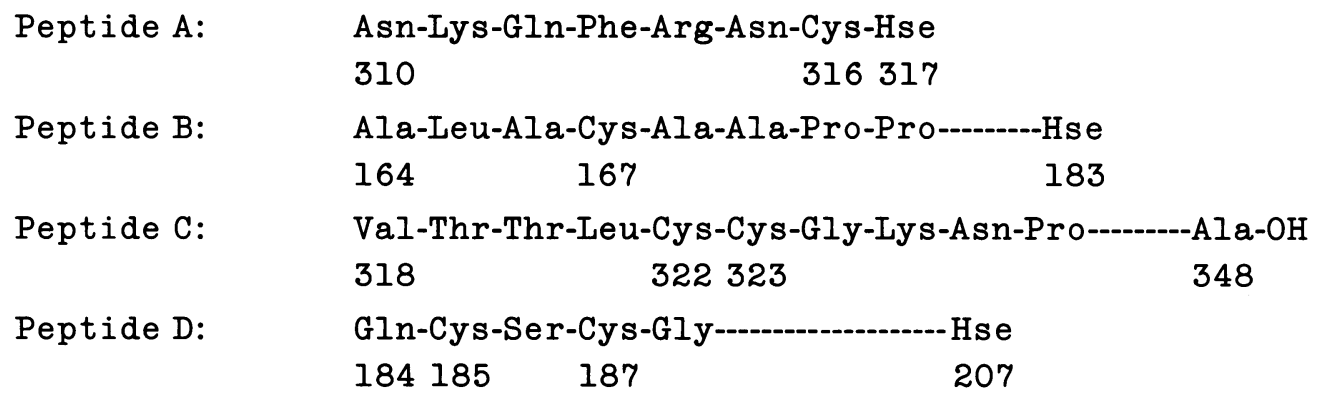

acetic acid $\left(5.3 \times 10^{6} \mathrm{~d}\right.$.p.m. $\left./ \mu \mathrm{mol}\right)$ and the doubly labelled percarboxymethylated protein isolated as described above. From the ${ }^{3} \mathrm{H}$ specific radioactivity of the abovementioned protein it was calculated that $3.3-3.6 \mathrm{~mol}$ of $-\mathrm{SH}$ groups had become available for alkylation after the reductive cleavage. That 8.9-9.6 -SH groups per molecule of rhodopsin were modified during the two stages agrees with the presence of a total of ten cysteine residues in the primary sequence of the protein $[7,8]$.

The $\left[{ }^{14} \mathrm{C},{ }^{3} \mathrm{H}\right]$ carboxymethylated protein was then subjected to $\mathrm{CNBr}$ cleavage [24] and the resulting mixture of peptides extracted into water; about $30 \%$ of the original radioactivity was found in the water-soluble fraction. Although the insoluble pellet from the above extraction could be solubilized in ethanol/formic
The sequence of peptide $\mathrm{C}$ showed that it represents the $C$-terminal portion of rhodopsin (residues 318-348) and the carboxymethylcysteine released at the fifth and sixth round of the Edman degradation contained exclusively ${ }^{3} \mathrm{H}$. This finding reveals that Cys-322 and Cys-323 must have been carboxymethylated after the reductive cleavage and thus these residues are mutually (see below) involved in the formation of a disulphide bond in the original protein. The reader should note that the conclusion, that these cysteine residues (Cys-322 and Cys-323) could not participate in disulphide-bond formation with other cysteine residues of the protein, follows from our previous work showing that papain treatment of rhodopsin cleaves the peptide bonds between residues 311 and 313, releasing the $C$-terminal portion of the molecule as what was designated as the 'light fragment' $[6,24,31]$. The release of the light 


\begin{tabular}{|c|c|c|c|c|c|}
\hline \multirow[t]{5}{*}{-6} & 4 & 14 & 24 & 34 & 44 \\
\hline & MNGT & EGPNFYVPFS & NKTGVVRSPF & EAPQYYLAEP & WQF SMLAAYM \\
\hline & MNGT & EGPNFYVPFS & NKTGVVRSPF & EAPQYYLAEP & ILAAYM \\
\hline & MNGT & EGPNFYVPFS & NATGVVRSPF & EYPQYYLAEP & WQF SMLAAYM \\
\hline & M & RKMSEEEFYL & FKN I SS VGPW & Z I I APV & AFM \\
\hline & SYE & DSTQSS IFTY & TNSNSTRGPF & EGPNYH I APR & WVYHLTSVWM \\
\hline & YE & DSTQSSIFTY & TNSNSTRGPF & EGPNYHIAPR & WVYHLTSVWM \\
\hline
\end{tabular}

54

64

74

FLLIMLGFP I NFLTLYVTVQ HKKLRTPLNY

FLLIVLGFPI NFLTLYVTVQ HKKLRTPLNY

FLLIVLGFPI NFLTLYVTVQ HKKLRTPLNY

GTVFLIGFPL NAMVLVATLR YKKLRQPLNY

IFVVTASVFT NGLVLAATMK FKKLRHPLNW

IFVVIASVFT NGLVLAATMK FKKLRHPLNW
$84 \quad 94 \quad 104$

ILLNLAVADL FMVFGGFTT LYTSLHGYFV

ILLNLAVADL FMVFGGFTT TYTSLHGYFV

ILLNLAVADL FMVLGGFTST LYTSLHGYFV

ILVNVSFGGF LLCIFSVFPV FVASCNGYFV

ILVNLAVADL AETVIASTIS IVNQVSGYFV ILVNLAVADL AETVIASTIS VVNQVYGYFV
(1)

(2)

(3)

(4)

(5)

(6)

(1)

(2)

(3)

(4)

(5)

(6)

(1)

(2)

(3)

(4)

(5)

(6)

(1)

(3)

(4)

(5)

(6)

AVWTAPPIFG WSRYWPHGLK TSCGPDVFSG SSYPGVQSYM IVLMVTCCII PLAIIMLCYL AVWTAPPIFG WSRYWPHGLK TSCGGDVFSG SSYPGVQSYM IVLMVTCCIT PLSIIVLCYL

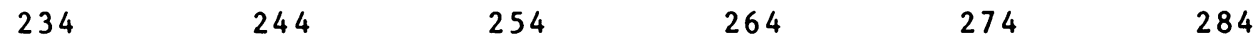
QLVFTVKEAA AQQQESATTQ KAEKEVTRMV IIMVIAFLIC WLPYAGVAFY IFTHQGSDFG QLVFTVKEAA AQQQESATTQ KAEKEVTRMV IIMVIAFLIC WLPYAGVAFY IFTHQGSDFG QLVFTVKEAA AQQQESATTQ KAEKEVTRMV IIMVIAFLIC WVPYASVAFY IFTHQGSNFG QLLRALKAVA AQQQESATTQ KAEREVSRMV VVMVGSFCVC YVPYAAFAMY MVNNRNHGLD QVWLAIRAVA KQQKESESTQ KAEKEVTRMV VVMIFAYCVC WGPYTFFACF AAANPGYAFH QVWLAIRAVA KQQRESESTQ KAEKEVTRMV VVMVLAFCFC WGPYAFFACF AAANPGYPFH

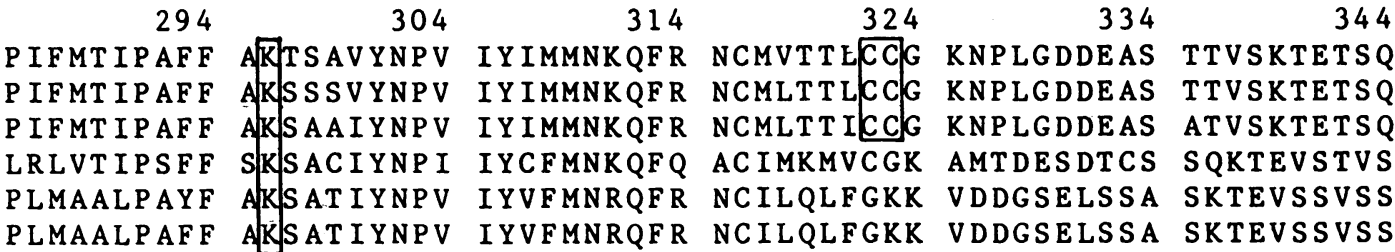

(4)

354

$\begin{array}{ll}\text { VAPA } & (1) \\ \text { VAPA } & (2) \\ \text { VAPA } & (3) \\ \text { STQVGPN } & (4) \\ \text { VSPA } & (5) \\ \text { VSPA } & (6)\end{array}$

Fig. 2. Comparison of the sequence of various mammalian rhodopsins

The alignments were made according to the guidance provided in ref. [14]: (1) Bovine rhodopsin [7,8]; $(2)$ ovine rhodopsin [10,11]; (3) human rhodopsin [13]; (4) human blue pigment [14]; (5) human green pigment [14]; (6) human red pigment [14]. The four cysteine residues involved in disulphide-bond formation in bovine rhodopsin, as well as the active-site lysine residues, are boxed. The residue numbers 1-348 correspond to the sequence of (1), (2) and (3).

Vol. 246 
fragment required no reductive treatment but merely denaturation.

The rod outer segments for these structural studies were obtained by using a method that does not employ a thiol reagent at any stage of the preparation [24]. In view of the unexpected finding of the presence of a disulphide bond between two adjacent cysteine residues, another series of experiments was undertaken in which $1 \mathrm{~mm}$-dithiothreitol was present throughout the preparation. In these cases the rod outer segments were stored in distilled water also containing $1 \mathrm{~mm}$-dithiothreitol. The suspension was then centrifuged to give a loose pellet that still contained some of the thiol-containing liquid, and this was subjected to non-reductive carboxymethylation using $\mathrm{O}_{2}$-free solutions and taking the utmost care to maintain a strictly anaerobic atmosphere with argon. Peptide $\mathrm{C}$ obtained from such experiments again contained ${ }^{3} \mathrm{H}$ only and on sequencing gave results identical with those in Fig. 1(c).

The search for other tritiated peptides resulted in the observation that, in the electrophoretogram at $\mathrm{pH} \mathrm{6.4,}$ some ${ }^{3} \mathrm{H}$ was present in a region $3-4 \mathrm{~cm}$ towards the cathode from the origin, but the band was too ill-defined to be suitable for further purification. To explore the nature of this ${ }^{3} \mathrm{H}$, an indirect strategy was therefore perceived. The entire mixture of water-soluble peptides, after treatment with trifluoroacetic acid, was attached to aminoproyl-glass via the homoserine coupling procedure. In principle this protocol should result in the immobilization to glass of peptides A and B and other peptides which contain a $C$-terminal homoserine residue (but not peptide $C$ ). The glass-bound peptide mixture was subjected to Edman degradation and from each cycle the mixture of PTH-amino acids was admixed with unlabelled PTH-carboxymethylcysteine. The samples were then processed for the separation of PTH-amino acids by h.p.l.c., but no attempt was made to identify the amino acid released. Instead, the peak corresponding to PTH-carboxymethylcysteine from cycles 1 to 8 was collected and radiochemically analysed (Fig. 1d).

As expected, ${ }^{14} \mathrm{C}$ was released in cycles 4 and 7 , and this radioactivity may be attributed to that from cysteine residues 167 and 316 in peptides $B$ and A respectively. The decay of this ${ }^{14} \mathrm{C}$ in subsequent turns $(5,6$ and 8$)$ is predictable from the data in Figs. $1(a)$ and $1(b)$ and arises from a relatively lower repetitive yield $(92-93 \%)$ in the Edman degradation. However, the presence of a significant amount of ${ }^{3} \mathrm{H}$ at the fourth cycle is the most noticeable feature of the experiments of Fig. 1(d). The examination of the sequence of bovine rhodopsin $[7,8]$ reveals that the only other $\mathrm{CNBr}$ peptide from the protein that may release a carboxymethylcysteine residue at the fourth cycle is that corresponding to the sequence 184-207 (peptide D; see above). It is therefore not unreasonable to assume that Cys-187 is predominantly modified during the stage of reductive carboxymethylation and that this residue may be hypothesized to be involved in the formation of the second disulphide bond of rhodopsin. Further work, though, will be needed to substantiate this deduction. It should be noted that an equal amount of ${ }^{3} \mathrm{H}$ and ${ }^{14} \mathrm{C}$ was released in cycle 4 of Fig. 1 $(d)$, thus suggesting that the molar fraction of the sequenceable peptide $D$ in the mixture was only one-fifth that of peptide B (since the ratio of specific radioactivities $\left({ }^{14} \mathrm{C} /{ }^{3} \mathrm{H}\right)$ of iodoacetic acid samples used in the two stages of carboxymethylation was 1:5). This disparity may be either due to the poor extractability of peptide $\mathrm{D}$ in water or due to its partial $N$-terminal blocking, attributed to cyclization of Gln-184 under acid conditions. Support for both these factors is provided by previous studies [10]. If in the fourth cycle ${ }^{3} \mathrm{H}$ was released from Cys-187 of peptide D, then the same peptide should release another PTH-carboxymethylcysteine at the second cycle. Indeed, we note from Fig. $1(d)$ that, at the second cycle, a significant amount of ${ }^{14} \mathrm{C}$ was found and its amount was about one-fifth that of the ${ }^{3} \mathrm{H}$ in the fourth cycle. The relationship would be expected if the ${ }^{14} \mathrm{C}$ in the second cycle were released from the same peptide which gave rise to PTH- $\left[{ }^{3} \mathrm{H}\right]$ carboxymethylcysteine at the fourth cycle. Attention should, however, be drawn to the presence of some ${ }^{3} \mathrm{H}$ in the second cycle. The level of ${ }^{3} \mathrm{H}$ was higher than can be explained in terms of background contamination. If we attribute this ${ }^{3} \mathrm{H}$ also to Cys-185 of peptide $\mathrm{D}$, then the conservative conclusion will be that at least $67 \%$ of the Cys-185 in native rhodopsin is present in -SH form and, hence, available for reaction with iodo $\left[{ }^{14} \mathrm{C}\right]$ acetic acid.

\section{DISCUSSION}

In order to identify the positions of the two disulphide bonds of bovine rhodopsin, the protein was subjected to carboxymethylation in two stages. The free - $\mathrm{SH}$ groups of rhodopsin were alkylated with iodo $\left[{ }^{14} \mathrm{C}\right]$ acetic acid and the disulphide bonds in the resulting protein were then reductively cleaved by using a high concentration of 2-mercaptoethanol. The -SH groups thus formed were modified by using iodo $\left[{ }^{3} \mathrm{H}\right]$ acetic acid. It was shown that two of the cysteine residues (Cys-167 and Cys-316) known to be present in rhodopsin in the - $\mathrm{SH}$ form $[18,19,21]$ were exclusively modified with ${ }^{14} \mathrm{C}$. Peptide $\mathrm{C}$, containing the $C$-terminal portion of rhodopsin, was found to be labelled with ${ }^{3} \mathrm{H}$ and the isotope was released in the fifth and sixth cycles of Edman degradation.

These results, when taken in conjunction with our previous experiments on the papain cleavage of rhodopsin into three fragments [6,24,31], unambiguously prove that Cys-322 and Cys-323 are mutually involved in the formation of one of the disulphide bonds of rhodopsin. It is noteworthy that the $C$-terminal part of the rhodopsin molecule contains the phosphorylation sites $[9,22,31]$ and participates in interaction with various proteins of the transduction system (for a review, see [22]). Whether a disulphide bridge in such a region is in any way involved in interaction with these proteins remains an interesting possibility. If this were the case, then the interaction will only operate in the rod pigments where these cysteine residues are conserved (see sequence comparison in Fig. 2).

These experiments, showing that four of the cysteine residues (at positions 167, 316, 322 and 323) were labelled with complete fidelity and contained only one of the two isotopes, unambiguously point to the fact that a generalized thiol disulphide exchange had not occurred during the modification(s), since, if this were the case, both isotopes would have been detected in at least one of these positions. The possibility that there may have been a specific thiol disulphide exchange between two unique residues during the original denaturation process, preceding non-reductive carboxymethylation, is not eliminated by the present work. In considering this possibility one would have to assume that, in detergent 
solution, a thermodynamically stable disulphide structure of the polypeptide chain is produced that is not available when the protein is present in the membrane. In the above experiments the time lapse between the addition of iodoacetic acid and SDS was kept to a minimum and was never more than $1 \mathrm{~min}$. The simultaneous addition of the two reagents could further minimize the chances of exchange reactions occurring, but could not totally exclude the possibility. Since under the unusual circumstances assumed for the occurrence of a 'specific' exchange, the rate of intramolecular exchange is bound to be much faster than the bimolecular reaction between a specific -SH group, still in the interior of the protein, and a rather poor electrophile like iodoacetic acid.

It should be pointed out that previous studies had noted that Cys-322 and Cys-323 were extremely resistant to alkylation and that this lack of reactivity was attributed either to the presence of a disulphide bridge between these residues [32] or to their location in an environment inaccessible to the reagent [20]. Indeed, during our own exploratory studies on the delineation of the topography of rhodopsin and the identification of its strategic groups [24,31], we had made several deductions, all except one of which have been borne out by more advanced experiments. The experiments described highlight that we were wrong in assuming that both the disulphide bonds of rhodopsin are present in a central core.

In the present study we have also provided indirect evidence to suggest that Cys-187 may be involved in the formation of the second disulphide bond, but have not identified the co-partner for this bridge. During the course of their extensive structural work on ovine rhodopsin, Findlay \& Pappin [22] deduced that Cys-110 is a part of a disulphide bond in the native protein. Combining this proposal with the results in the present paper allows us to hypothesize that the second disulphide bond in rhodopsin is formed via Cys-110 and Cys-187. This conclusion is consistent with the prediction made from the examination of a structural model of rhodopsin that Cys-110 and Cys-185/Cys-187 are suitably juxtapositioned to permit the formation of a disulphide bond [22]. More interestingly, the cysteine residues corresponding to positions Cys-110 and Cys-187 in bovine rhodopsin are conserved in all visual pigments examined to date (Fig. 2), thus suggesting their importance in a structural or functional role. Notwithstanding these considerations, it should be emphasized that the case for the existence of a disulphide bond between Cys-110 and Cys-187 is based upon indirect, and hence weak, evidence and will require validation by an unambiguous identification of the type which has been achieved to show the presence of a -S-S- bond between Cys-322 and Cys-323.

\section{Note added in proof (received 22 June 1987)}

The residues corresponding to Cys-110, Cys-187, Cys-322 and Cys-323 are also conserved in Drosophila (fruitfly) rhodopsin [33].

We thank the Ulverscroft Foundation and Science and Engineering Research Council for generously supporting our work on vision, and the King Saud University, Saudi Arabia, for a Scholarship to S. A.-S. We thank Dr. Ian G. Giles for his assistance with computer programs to allow the comparison of protein sequences and the calculation of the repetitive yields obtained in the Edman-degradation procedures.

\section{REFERENCES}

1. Matthews, R. G., Hubbard, R., Brown, P. K. \& Wald, G. (1963) J. Gen. Physiol. 47, 215-240

2. Akhtar, M., Blosse, P. T. \& Dewhurst, P. B. (1965) Life Sci. 4, 1221-1226

3. Akhtar, M., Blosse, P. T. \& Dewhurst, P. B. (1968) Biochem. J. 110, 693-702

4. Bownds, D. (1967) Nature (London) 216, 1178-1181

5. Mullen, E. \& Akhtar, M. (1981) FEBS Lett. 132, 261-264

6. Mullen, E. \& Akhtar, M. (1963) Biochem. J. 211, 45-54

7. Ovchinnikov, Y. A. (1982) FEBS Lett. 148, 179-191

8. Ovchinnikov, Y. A., Abdulaev, N. G., Feigina, M. Y., Artamonov, I. D., Zolotarev, A. S., Kostina, M. B., Bogachuk, A. S., Miroshnikov, A. I., Martinov, V. I. \& Kudelin, A. B. (1982) Bioorg. Khim. 8, 1424-1427

9. Hargrave, P. A., McDowell, J. H., Curtis, D. R., Wang, J. K., Juszczak, E., Fong, S. L., Mohanna Rao, J. K. \& Argos, P. (1983) Biophys. Struct. Mech. 9, 235-244

10. Brett, M. \& Findlay, J. B. C. (1983) Biochem. J. 211, 661-670

11. Findlay, J. B. C., Barclay, P. L., Brett, M., Davison, M., Pappin, D. J. C. \& Thompson, P. (1984) Vision Res. 24, 1501-1508

12. Nathans, J. \& Hogness, D. S. (1983)Cell (Cambridge, Mass.) $34,807-814$

13. Nathans, J. \& Hogness, D. S. (1984) Proc. Natl. Acad. Sci. U.S.A. 81, 4851-4855

14. Nathans, J., Thomas, D. \& Hogness, D. S. (1986) Science 232, 193-202

15. Nathans, J., Piantanida, T. P., Eddy, R. L., Shows, T. B. \& Hugness, D. S. (1986) Science 232, 203-210

16. Pappin, D. J. C. \& Findlay, J. B. C. (1984) Biochem. J. 217, 605-613

17. De Grip, W. J., van de Laar, G. L. M., Daemen, F. J. M. \& Bonting, S. L. (1973) Bioch. Biophys. Acta 325, 315-322

18. Barclay, P. L. \& Findlay, J. B. C. (1984) Biochem. J. 220, 75-84

19. Davison, M. D. \& Findlay, J. B. C. (1986) Biochem. J. 236, 389-395

20. Davison, M. D. \& Findlay, J. B. C. (1986) Biochem. J. 234, 413-420

21. McDowell, J. H. \& Griffith, K. (1978) Invest. Opthalmol. Visual Sci. 17 (Suppl.), 125

22. Findlay, J. B. C. \& Pappin, D. J. C. (1986) Biochem. J. 238, 625-642

23. Wachter, E., Machleidt, W., Hofner, H. \& Otto, J. (1973) FEBS Lett. 35, 97-102

24. Sale, G. J., Towner, P. \& Akhtar, M. (1977) Biochemistry 16, 5641-5649

25. Steers, E., Craven, G. R., Anfinsen, C. B. (1965) J. Biol. Chem. 240, 2478-2484

26. Laursen, E. A., Horn, M. J. \& Bonner, A. G. (1972) FEBS Lett. 21, 67-70

27. Chang, J. Y., Creaser, E. H. \& Hughes, C. J. (1977) FEBS Lett. 84, 187-190

28. Horn, M. J., Laursen, R. A. (1973) FEBS Lett. 36, 285-288

29. Laursen, R. A. (1971) Eur. J. Biochem. 20, 89-102

30. Edman, P. (1950) Acta Chem. Scand. 4, 277-282

31. Sale, G. J., Towner, P. \& Akhtar, M. (1978) Biochem. J. $175,421-430$

32. De Grip, W. J. \& Daemen, F. J. M. (1982) Methods Enzymol. 81, 223-236

33. O'Tousa, J. E., Baehr, W., Martin, R. L., Hirsh, J., Pak, W. L. \& Applebury, M. L. (1985) Cell (Cambridge, Mass.) 40, 839-850 